\title{
Advances in the propagation of Jabuticaba tree
}

\author{
José Antonio Alberto da Silva ${ }^{1}$, Gustavo Henrique de Almeida Teixeira², Antonio Baldo Geraldo Martins ${ }^{2}$, \\ Idemir Citadin 3 , Américo Wagner Júnior ${ }^{3}$, Moeses Andrigo Danner ${ }^{3}$
}

\begin{abstract}
The Myrtaceae family has representatives spread worldwide, and Jabuticaba tree is an important species native to Brazil, which is grown not only in the backyards and domestic orchards, but also in commercial orchards, landscaping projects and in several tropical and subtropical countries. The propagation of this species in a sexual form or by seeds is simple and efficient, being able to reach $100 \%$. However, long juvenile phase and genetic segregation have led to the search for methods that allow the propagation of selected trees and guarantee through their standardized and productive clones, fruit quality and fruiting precocity. Protocols for asexual propagation are still scarce, but they show efficient methods, making possible the commercial use and valorization of this Brazilian fruit tree. Grafting methods have proven to be efficient in more than $70 \%$ of cases. Herbaceous cutting in Jabuticaba trees shows rooting around $10 \%$. Air layering shows rooting rates above $80 \%$. Other methods considered for domestic use have shown satisfactory results in the formation of young saplings through woody cuttings. New studies on micropropagation and better control of herbaceous stem cutting processes could stimulate and economically increase the propagation of this fruit tree for commercial crops to produce fruits for fresh consumption or processing. Air layering and grafting are the most currently indicated methods for propagation of jabuticaba tree. This review paper shows the results of other papers and their protocols for obtaining jabuticaba tree seedlings and clonal plants.
\end{abstract}

Index terms: Myrtaceae, Plinia sp., Grafting, Cutting, Air layering, Cloning.

\section{Corresponding author:} jaas@apta.sp.gov.br

Received: June 08,2018 Accepted: September 21, 2018

Copyright: All the contents of this journal, except where otherwise noted, is licensed under a Creative Commons Attribution License.

\section{(cc) $\mathbf{E Y}$}

\section{Avanços na propagação da Jabuticabeira}

Resumo - Dentre a família Myrtaceae com representantes espalhados por todo o planeta, a jabuticabeira é uma importante espécie nativa do Brasil e que passou a ser apreciada não só nos limites de quintais e pomares domésticos, mas já pode ser encontrada em pomares comercias, projetos de paisagismo e em vários países com clima tropical e subtropical. A propagação desta espécie de forma sexuada ou via sementes é bastante simples e eficiente, podendo chegar a $100 \%$. Porém, o longo período de juvenilidade e a segregação têm levado à busca por métodos que permitam propagar matrizes selecionadas e garantir, em seus clones, plantas padronizadas e produtivas, a qualidade dos frutos e a precocidade na frutificação. Os protocolos para propagação assexuada ainda são escassos, mas mostram métodos eficientes, viabilizando a exploração comercial e a valorização desta frutífera brasileira. $\mathrm{O}$ método de enxertia em garfagem têm-se mostrado eficiente em mais de $70 \%$ dos casos. A estaquia herbácea mostra enraizamento em torno de $10 \%$. A alporquia com índices de enraizamento acima de $80 \%$. Outros métodos considerados de uso doméstico têm mostrado resultados satisfatórios na formação de mudas de jabuticabeira através de estacas lenhosas. Novos estudos, como a micropropagação e melhor controle nos processos de estaquia herbácea, devem estimular e viabilizar economicamente a multiplicação desta frutífera para cultivos comerciais, seja para produção de frutos frescos, seja para processamento. A alporquia e a enxertia em garfagem são os métodos mais indicados atualmente para propagação de jabuticabeira. Neste artigo de revisão constam resultados de trabalhos e protocolos para obtenção de mudas de jabuticabeira.

Termos para indexação: Myrtaceae, Plinia sp., Enxertia, Estaquia, Alporquia, Clonagem.

\footnotetext{
${ }^{1}$ Pesquisador, Agência Paulista de Tecnologia dos Agronegócios (APTA), Polo Alta Mogiana, Colina - SP. Brasil. E-mail: jaas@apta.sp.gov. $\mathrm{br}^{\text {(ORCID 0000-0003-0813-0793) }}$

${ }^{2}$ Prof. Dr.,"Departamento de Produção Vegetal, Universidade Estadual Paulista, Faculdade de Ciências Agrárias e Veterinárias,Jaboticabal-SP. Brasil. E-mails: gustavo@fcav.unesp.br (ORCID 0000-0002-7179-080X); toninhobgm@hotmail.com (ORCID 0000-0002-4946-9104)

${ }^{3}$ Prof. Dr. Departamento de Fruticultura ,Universidade Tecnológica Federal do Paraná, Câmpus Pato Branco. Pato Branco-PR. Brasil. E-mails: idemir@utfpr.edu.br (ORCID 0000-0001-9416-2761) ; americowagner@utfpr.edu.br ${ }^{\text {(ORCID 0000-0001-5081-5281) }}$; moesesandrigo@yahoo.com.br ${ }^{\text {(ORCID }}$ 00000-0002-1159-6546)
} 


\section{Introduction}

'Jabuticaba' or 'Jaboticaba' tree is a Brazilian native fruit tree, extremely curious to produce perfumed and sweet flowers that result in rounded, black, tasty and sweet fruits, grouped in the trunk in the branches. They belong to the Myrtaceae family and to the Plinia genus, it being recognized nine species. The two species with the highest expression in cultivation are: Plinia jaboticaba (Vell.) Berg, of which stands out the 'Sabará' type, the most planted in Brazil; and P. cauliflora (Mart.) Kausel, also known as 'Jabuticabeira-açu', 'Ponhema' or 'Paulista'. The name of Tupi origin Iapoti'kaba, refers to the "fruit-in-bud" because of its rounded shape.

In the Southwestern region of the State of Paraná (Brazil), P. cauliflora occurs in the forest fragments of 'Araucaria' forest. The adult native 'Jabuticaba' tree of this region account for at least 4,000 individuals, composed of tall trees, with an average of 15 meters in height and $41 \mathrm{~cm}$ in diameter at the breast height (DANNER et al., 2010). There are still no varieties but types, since several studies have shown their diversity, as reported by Cruz et al. (2016), where they observed that 'Jabuticaba' trees, apparently of the same species (Plinia sp.), have high genetic variability.

The species is endemic to Brazil and has been widely used in urban yards for the fruits yield and also for landscaping. This is due to the beauty of flowering and fruiting by cauliflory in the trunk and branches. The 'Jabuticaba' trees are very appreciated in Brazil for natural consumption or as jelly and liqueurs, due to the sensorial and functional quality (BALERDI et al., 2006). This fruit also presents potential for pharmaceutical, cosmetic and food industries. The 'jabuticaba' bark has a high content of flavonoids and anthocyanins that combat free radicals (DANNER et al., 2011a). The flour from the bark, given to mice resulted in reduction of prostate cancer and leukemia (MILK-LEGATTI et al., 2012) and reduced cholesterol and diabetes (LENQUISTE et al., 2012).

Despite this potential, commercial orchards are few, but the most notable are those at Casa Branca city in the State of São Paulo (Brazil), which supply 'Ceagesp' with almost 2,000 tons per year and the orchard with more than 41 thousand 'Jabuticaba' trees planted, mainly with 'Sabará' and 'Pingo de mel' types at Hidrolândia city, State of Goiás (Brazil), divulged in national television news. The festivals based on gastronomic tourism, with derivatives and dishes based on 'Jabuticaba' are prominent in some cities, for example, in Sabará, State of Minas Gerais (VIEIRA; FERREIRA, 2013).

The production of 'Jabuticaba' seedlings in nurseries has been carried out mainly by seeds due to the easiness and speed of obtaining the seedlings and also due to certain difficulty in rooting of cuttings when used the asexual propagation. However, the juvenile period of this plant from seeds can have eight to 10 years. To reduce the juvenility time and maintain mother plant characteristics by cloning, the production of 'Jabuticaba' tree can also be done by grafting or air layering.

\section{SEXUAL PROPAGATION}

\section{Production of seedlings by seeds}

The production of seedlings by seeds has the disadvantages of: 1) do not generate clones (there will be genetic heterogeneity in the progeny generated); and 2) delay in coming to production, due to the juvenile period of the seedlings. The 'Jabuticaba' trees have a juvenile period among the longest of the fruit species, around 10-20 years.

Some 'Jabuticaba' seeds are polyembryonic, that is, they have more than one embryo per seed, resulting in more than one seedling (Figure 1). Polyembryony variable rates from 0 to $75 \%$ of seeds of each mother plant as observed by Danner et al. (2011a), with an average number of emerged plantlets from seeds between 1.3 and 1.6 (WAGNER JUNIOR et al., 2011). If polyembryony, which occurs in 'Jabuticaba' seeds, is generated by apomixis (formation of embryos without fertilization), depending on the type of polyembryony, some of the seedlings generated will be clones of mother plant. That is, it is possible to obtain clones by seeds. Despite this, the juvenile period of these seedlings should remain long. In addition, if apomixis occurs in 'Jabuticaba' trees by the adventitious embryo mechanism, which occurs in Mangifera indica, 'Mango' tree (CORDEIRO et al., 2006) and in some Citrus (RUIZ et al., 2000) species, the seeds must have a zygotic embryo (from fertilization) and other apomythic embryos (matrix clones), it can be identified with the use of molecular markers of microsatellite type, since the seedlings generated by apomixis have a genetic profile identical to the mother plant, of which they are clones, whereas the seedlings of zygotic (sexual) embryos are genetically different from the mother plant (RUIZ et al. (2000) BRESSAN et al., 2013).

'Jabuticaba' seeds are recalcitrant because they totally lose their viability when their moisture content is close to $10 \%$, which occurs in only 10 days of storage at room temperature. However, 'Jabuticaba' seeds can be stored for up to 65 days in vacuum packaging, with seeds immersed in phosphate-based buffer solution and $\mathrm{pH}=$ 7.0 , with viability (germination) of $40 \%$ (DANNER et al., 2011b).

In order to obtain 'Jabuticaba' seedlings by seeds, they must be extracted from the ripe fruits and sown soon after harvest. The seeds should be cleaned by removing the mucilage using a paste of virgin lime for 30 minutes, followed by rubbing the seeds in fine mesh sieve and running water. If this is done, the emergency will be close to $100 \%$ (DANNER et al., 2011b). 
The sowing should be done with the fruits largest seeds (WAGNER JÚNIOR et al., 2011), in seedlings bags of large size (volume of approximately 2.0 liters) and containing fertile substrate, as, for example, soil mixture of native forest and vermicompost $(1: 1, \mathrm{v}: \mathrm{v})$ since the growth of the seedlings was higher under these conditions, allowing the production of seedlings suitable for planting in the field in 12 months.

As for the juvenile period of the 'Jabuticaba' tree propagated by seeds is long, there is an exception, this when speaking of 'Jabuticaba' tree denominated 'Hybrid'. The origin of this 'Hybrid is unknown, but its bloom and fruit are early, even when used the seeds (after 3 to 5 years of sowing). The other advantages are the low tree size and the occurrence of several blooms and fruiting during the year. 'Hybrid Jaboticaba' is being intensively spread by nurseries and grown in urban, rural and landscaping yards, mainly in the South and Southeast regions of Brazil (unpublished information).

\section{ASEXUAL PROPAGATION}

\section{Propagation by cuttings}

Cutting is a technique of propagation that has shown rooting rate considered low in 'Jabuticaba' trees, ranging from $2.6 \%$ to $66.6 \%$. In addition, the studies indicated that the highest rooting was promoted with the use of softwood cuttings, which requires high concentrations of indole-butyric acid (IBA) and a structure with high humidity in the substrate and in the cuttings must have leaf. The use of intermittent nebulization and even heating of the substrate are good too (LEONEL et al., 1991; DUARTE et al., 1997; SCARPARE FILHO et al., 1999; CASAGRANDE JÚNIOR et al., 2000; PEREIRA et al., 2005; SASSO et al., 2010a). This makes the propagation process more expensive and restricts its use.

However, Duarte et al. (1997) tested rooting of terminal cuttings with three to four pairs of newly-ripened leaves of 'Jaboticaba' tree, obtained $60 \%$ of rooting on cuttings with four longitudinal cuttings at the base and treated with $1,000 \mathrm{mg} \mathrm{L}^{-1}$ of IBA and it kept in hermetic plastic chamber, during the time of the year without occurrence of stress due to low temperatures and humidity.

Apical softwood cuttings from the last growth cycle were used by Sasso et al. (2010a) in two seasons (October and December). In a greenhouse with controlled temperature $\left(15-28^{\circ} \mathrm{C}\right)$, cuttings with 2 to $3 \mathrm{~mm}$ in diameter, 5 to $7 \mathrm{~cm}$ in length, two whole leaves at the apical end and a bevel cut base next to a vegetative gem, were planted on the substrate up to half their length, in transparent plastic trays with a lid $(20 \times 9 \times 15 \mathrm{~cm}=$ $2,700 \mathrm{~cm}^{3}$ ), containing expanded vermiculite, moistened daily (Figure 2). The maximum rooting of $10 \%$ was obtained in the cuttings collected in October, treated with
2,000 to 4,000 $\mathrm{mg} \mathrm{L}^{-1}$ IBA concentrations and the leaves were kept.

The authors mentioned above, with softwood cuttings of 'Jabuticaba' tree, indicate a low percentage of rooting, when compared to other fruit trees. Leonel et al. (1991) studied the effect auxins and boric acid applications, only observed the formation of callus in the base of semiwoody cuttings of $P$. cauliflora, without rooting. On the other hand, Scarpare Filho et al. (1999) obtained rooting of up to $38 \%$ of $P$. jaboticaba cuttings originating from new sproutings after drastic pruning of the mother plant. Duarte et al. (1997) verified up to $60 \%$ of rooting of apical softwood cuttings of 'Jabuticaba' tree ( $P$. cauliflora), treated with $1000 \mathrm{mg} \mathrm{L}^{-1}$ of IBA and subjected to the hermetically sealed polyethylene chamber, under $50 \%$ shading. For Pereira et al. (2005), the rooting of the apical cuttings of 'Sabará' 'Jabuticaba' tree (P. jaboticaba) was up to $39.6 \%$, being influenced by the $\mathrm{pH}$ values of the substrate.

According to Sasso et al. (2010a), in general, the rejuvenation and drastic pruning in the mother plant, the use of specific plant regulators, intermittent nebulization and substrate heating are strategies that should increase the rooting of 'Jabuticabeira's softwood cuttings.

The cuttings with long branches or woody cuttings have been popularly used, but with little scientific study on the procedures.

One of the methods uses woody and branches heavily covered by leaves, collected from 'Jabuticaba' trees in productive phase. Branches of 1.5 to $2.0 \mathrm{~cm}$ in diameter and 1 to $1.2 \mathrm{~m}$ in length are prepared in a shaded location immediately after the cut from the mother plant. They make 4 to 6 vertical cuts in the bark with the blade, in the region where it will be buried, and emit the roots. The base of the branch will be inside a PET bottle with a capacity of $1 \mathrm{~L}$ of water. The bottle is buried with the branch in a plastic vase for budwoods, filled with fertile soil, up to $15 \mathrm{~cm}$ above the bottleneck of the bottle, which, although buried. It should be replenished with water every four days; for this purpose, the tip of a hose is held inside the bottle for replenishment (Figure3).

Sasso et al. (2010a) tested the effectiveness of the rooting method of woody cuttings with bottle in the base, and they obtained, after 180 days, the rooting of $50 \%$ of the woody cuttings, but the rooting was dependent on the use of IBA in the concentration of $6,000 \mathrm{mg} \mathrm{L}^{-1}$, soaked in cotton and fixed in the region of the vertical cuts in the branches.

Another method uses cuttings $80 \mathrm{~cm}$ in length and five to seven centimeters in diameter. At the basal end, a cross-cut is made, of $15 \mathrm{~cm}$ of depth, and a double bevel cut at the tip as if it was pointing a pencil. Then, the cutting is poked into the soil with a sledgehammer, setting the base $40 \mathrm{~cm}$ deep and maintaining irrigation for at least three times a week. At the other end of the cutting is placed a 
wad of organic substrate or wet sphagnum, bound with a plastic, in order to maintain moisture (Figure 4). In this way, the cuttings that take root will flourish from the second year (unpublished information).

Another popular technique for the formation of 'Jabuticaba' tree is to use long and covered by leaves branches with $1.5 \mathrm{~m}$ in length, from plant in production. A hole is drilled in the bottom of a plastic pot or 20-liter can, where it crosses the base of the cutting through the pot, leaving some $30 \mathrm{~cm}$ of the branch below the base of the pot. Fill the pot with fertile soil, and the branch tip at the bottom should be immersed in water by placing another container (Figure 7). The irrigation of the pot and the replacement of water in the lower container should be periodic. After observing a good rooting and new shoots in the crown, the branch under the pot is cut, and the seedling is ready, and it should start flowering after the second or third year (unpublished information).

\section{Propagation by grafting}

'Jaboticaba' propagation by grafting is feasible because it generates sprouting rate above $70-80 \%$ (SAMPAIO, 1984; SASSO et al, 2010b.). The rootstocks should be prepared with seedlings from nursery seeds (under the conditions mentioned above), with 12 to 24 months of age, having a diameter of 0.8 to $1.2 \mathrm{~cm}$, at 20$25 \mathrm{~cm}$ from the base.

For Donadio (2009), the grafting should be done by top clef grafting, preferably in May or August. The grafts are apical branches with a diameter similar to that of rootstocks ( 0.8 to $1.2 \mathrm{~cm}$ ), collected from selected mother plants and without occurrence of flowering and/or fruiting, so that the branches have well-nourished buds to sprout.

For the grafting, one of the branches of the rootstock is cut at $20-25 \mathrm{~cm}$ from the base, remaining one of the other branches to produce energy via photosynthesis, to nourish the shoots of the graft. In the cut branch, a central longitudinal incision is made, with a depth of $3.0 \mathrm{~cm}$. The graft is prepared $10 \mathrm{~cm}$ in length, the leaves are removed, the apex is protected with plastic wrap or paraffin, and the base is cut on both sides, $3.0 \mathrm{~cm}$ long in a wedge shape. Then, the graft wedge is inserted into the longitudinal section of the rootstock, in order to have the best juxtaposition possible (Figure 5). The lashing is then made with grafting tape, which can be removed after 60-90 days of grafting to verify healing. If sprouting of grafts occurs, the branches should be removed from the rootstock after this period to allow growth and formation of the grafted seedling (SASSO et al., 2010b).

Thus, grafting can be used to propagate 'Jabuticaba' plants in large scale, because it provided up to $73 \%$ of plant formation, according to the method used by Sasso et al. (2010b), obtain success with $85 \%$ sprouts, not differing among P. cauliflora, P. jaboticaba and $P$. peruviana species, grafted on two-year seedlings of $P$. jaboticaba 'Sabara', by top cleft grafting; however, it should be avoided to use grafts collected in the flowering and fruiting phases.

In addition, Sampaio (1984) observed that summer grafting of $P$. jaboticaba on $P$. cauliflora seedlings resulted in $30.5 \%$ survival, while using approach grafting during autumn-winter of $P$. cauliflora on seedlings of the same species, $80 \%$ of survival was obtained.

\section{Propagation by air layering}

Air layering is a propagation technique in which the branch stays connected to the mother plant until the rooting. This technique is little used in fruit species, due to the greater difficulty of execution, concerning to cuttings and grafting. However, it is advantageous for woody species that are difficult to rooting of cuttings, such as 'Jabuticaba' tree, for which rooting of up to $100 \%$ of the air layering has been made (DANNER et al., 2006).

In order to carry out the 'Jabuticaba' tree by air layering, a branch should be chosen in the mother plant with a diameter of $2.0-2.5 \mathrm{~cm}$, a $1.5-2.0 \mathrm{~cm}$ peel ring should be removed and cover that with cotton soaked in the solution of IBA of $4,000 \mathrm{mg} \mathrm{L}^{-1}$. Cover this area of the girdling with a transparent and resistant plastic bag containing commercially moistened substrate, tying the plastic at the ends (Figure 6). The roots are seen externally to the substrate after 180 days. The air layering can be done at any time of year, except when there is occurrence of flowering or fruiting (DANNER et al., 2006; SASSO et al., 2010b.). After disconnecting from the mother plant, it should be placed in 25 -liter pots, kept in a nursery with sprinkler irrigation for 12 months, for root and shoot growth, before planting in a definitive location. 
A

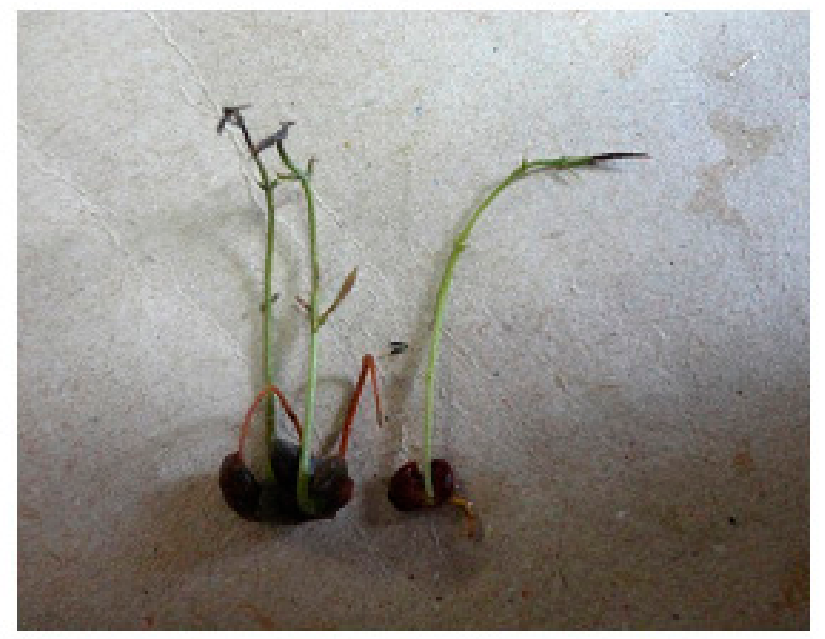

B

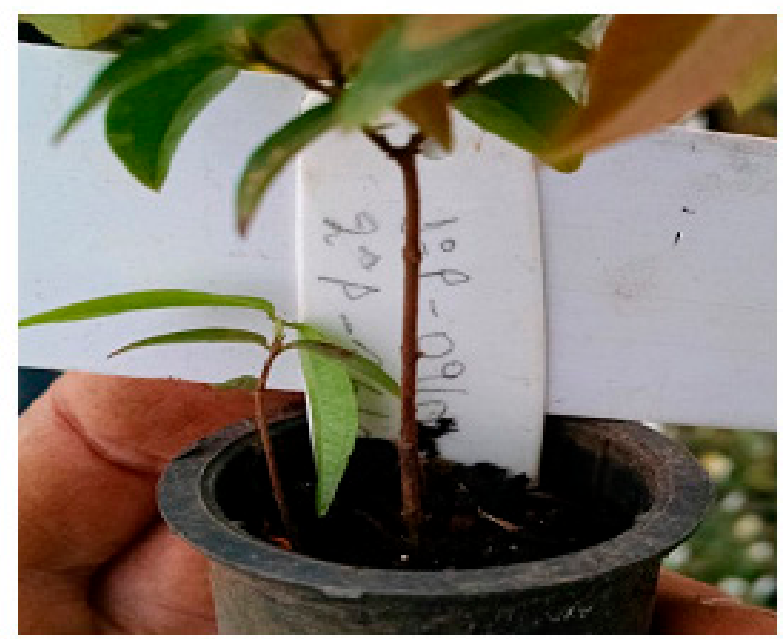

Figure 1 - Germination (A) of one (right) and two (left) seedlings of seeds of Jabuticaba tree (Plinia cauliflora) kept in a growth chamber at $25^{\circ} \mathrm{C}$; and emergence (B) of two seedlings of a seed in tubes with substrate, kept in nursery. (Photos: Moura, A.P.C.)

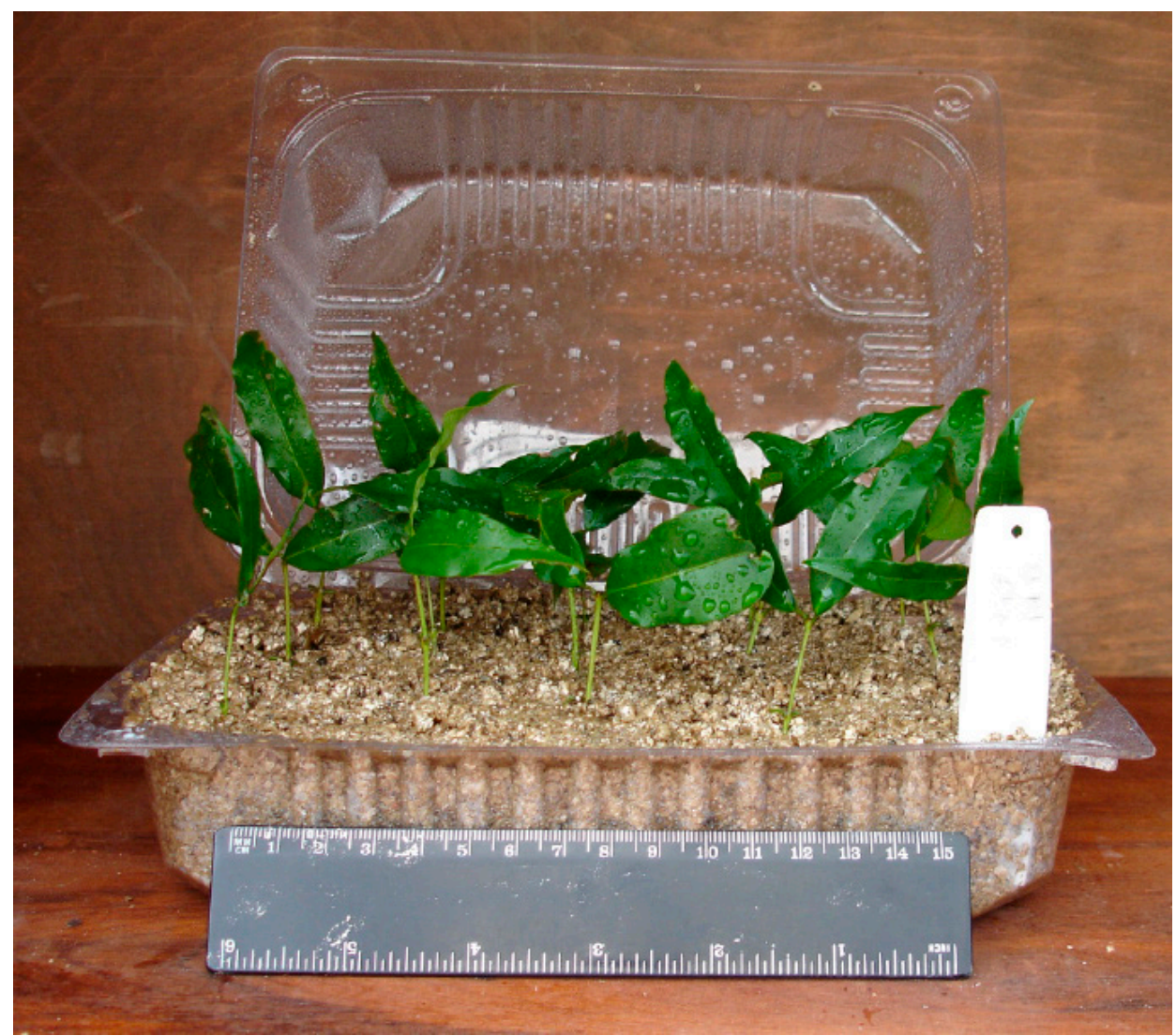

Figure 2 - Tray with softwood terminal cuttings of Jabuticaba tree. (Photo: Sasso, S.A.Z) 
A

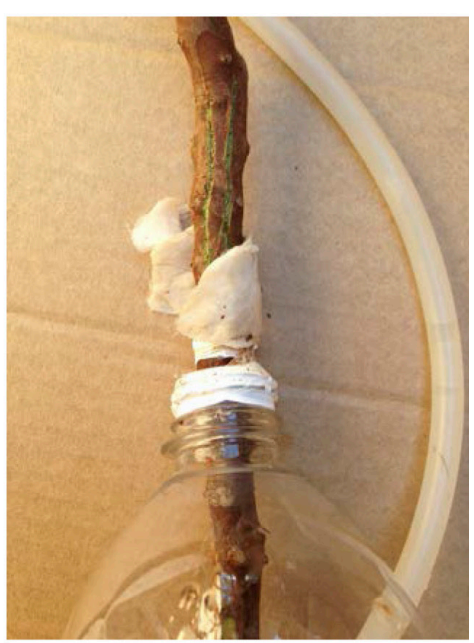

B

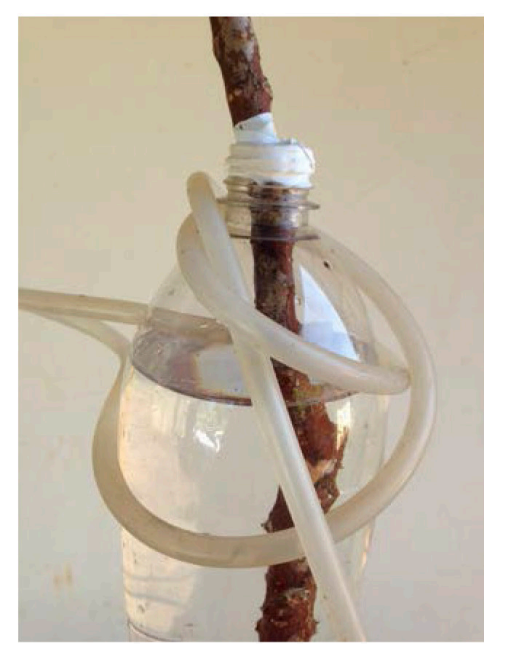

$\mathrm{C}$

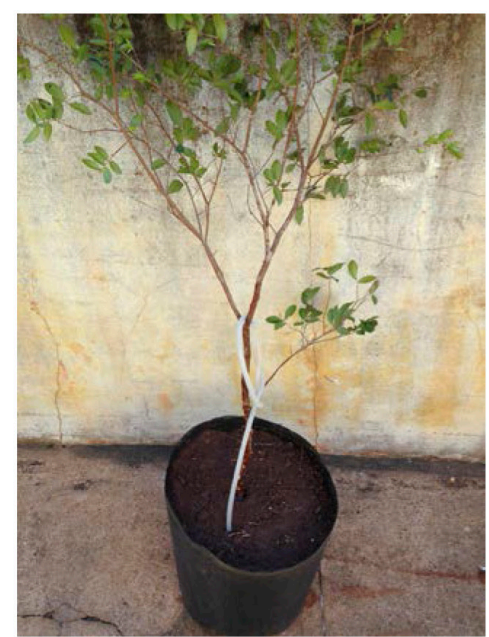

Figure 3 - Long cutting with vertical cuts soaked in cotton with IBA (A), in Pet bottle with water replacement hose (B), planted in 30 L pot (C). (Photos: Silva, J.A.A)
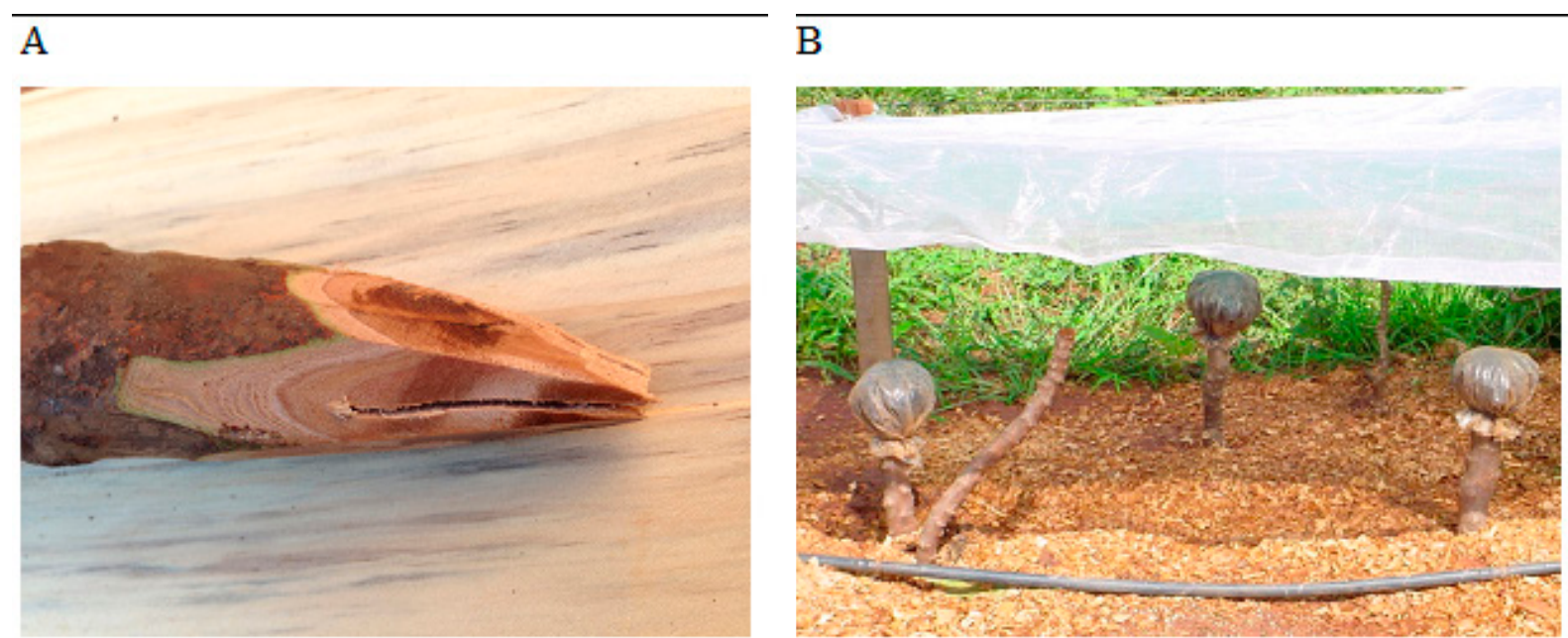

Figure 4 - Long cutting with sharp base (A); stuck cuttiruys (B). (Photo: Silva, J.A.A)

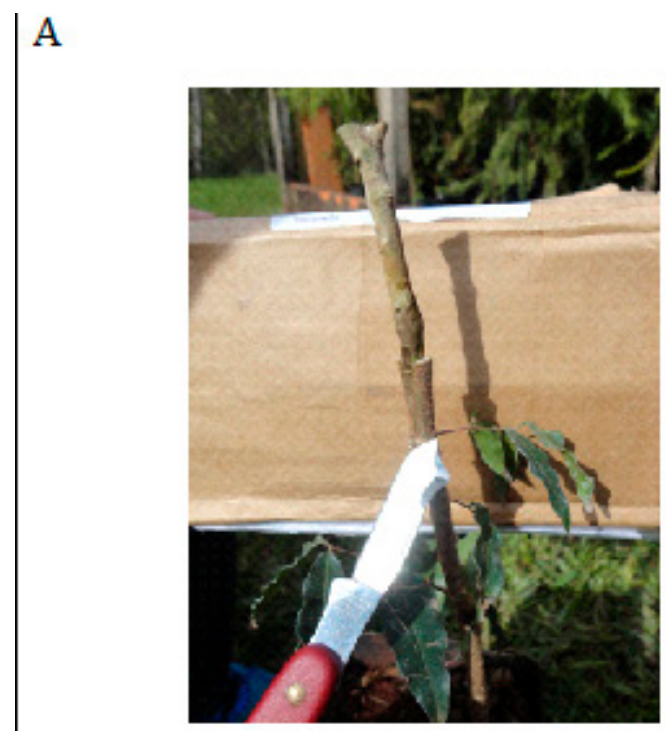

\section{B}

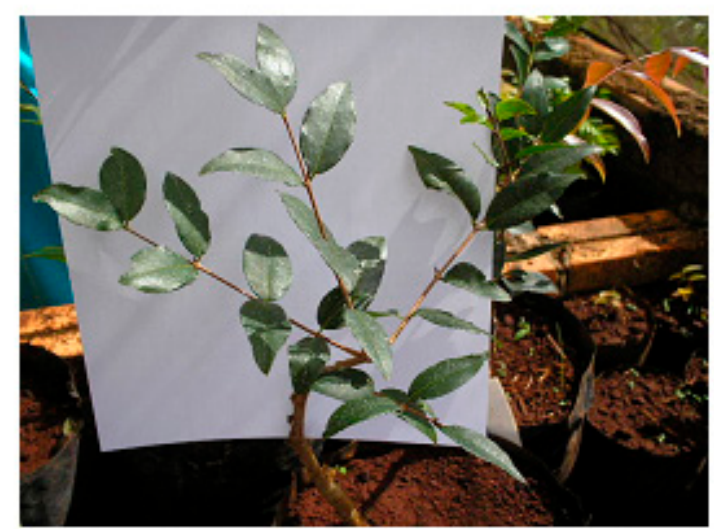

Figure 5 - Grafting by top clef grafting in Jabuticaba tree (Plinia cauliflora): detail of juxtaposition of graft and rootstock, before tying with tape (A) and sprouts after six months of grafting (B). (Photos: Moura, A.P.C.; Danner, M.A) 
A

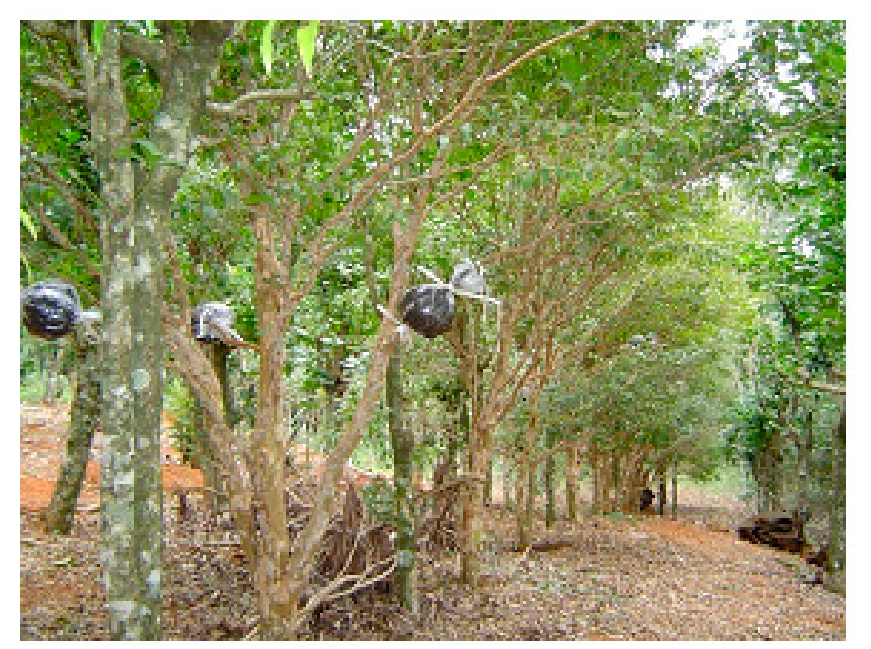

B



Figure 6 - Air Layering held in Jabuticaba tree-matrix (A) and rooted air layering disconnected from the matrix plant, after 180 days of the aerial (B). (Photos: Danner, M.A)

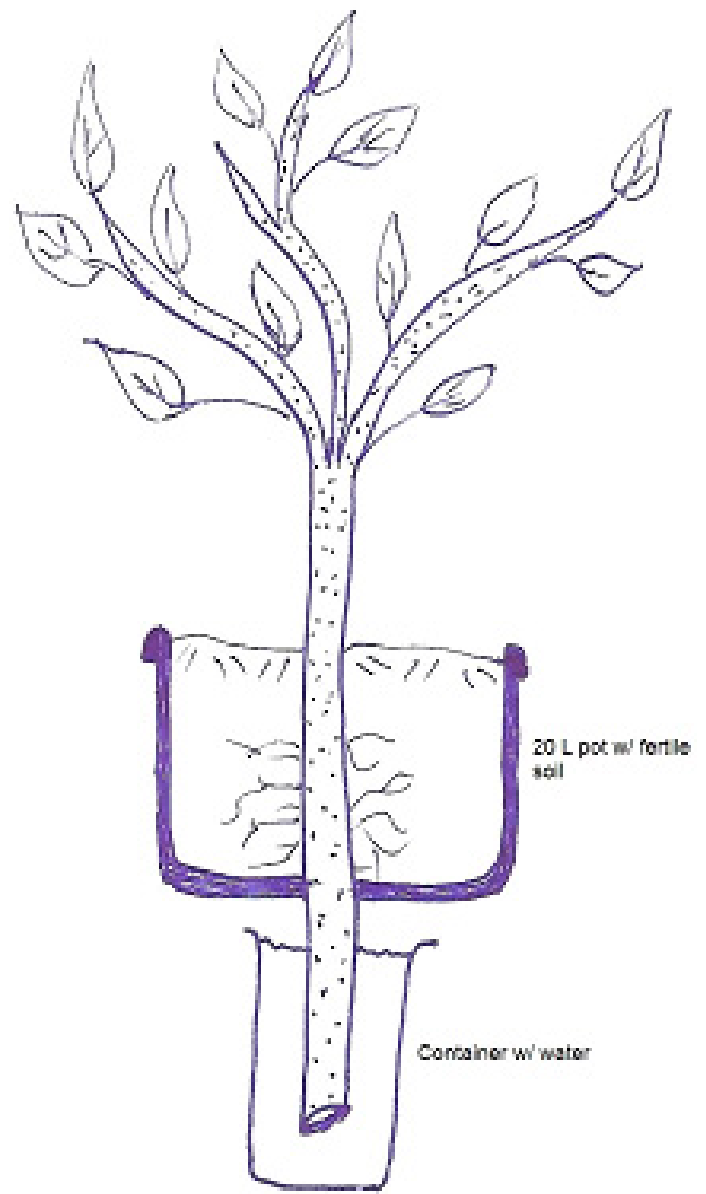

Figure 7 - Rooting scheme for long cutting of Jabuticaba tree. (Illustration: Silva, J.A.A) 
Table 1 - Publications in scientific journals on propagation of Jabuticaba trees (Plinia sp.) by grafting, cuttings and air layering, in increasing chronological order

\section{$\begin{array}{lll}\text { Title }^{1} & \text { Quote } & \text { Rooting or sprouting }\end{array}$}

Grafting Propagation of 'Sabarazeiro' (M. jaboticaba Berg) ～Sampaio (1984) ～up to 85\%

\begin{tabular}{lcc}
\hline Effect of phytoregulators and boric acid application on Jabuticaba & Leonel et al. \\
tree cuttings $(M$. cauliflora Berg.) & $(1991)$ & $0.0 \%{ }^{6}$
\end{tabular}

tree cuttings (M. cauliflora Berg.)

(1991)

$\begin{aligned} & \text { Propagation of Jaboticaba tree (M. cauliflora (Mart.) Berg) by } \\ & \text { terminal leafy cuttings }\end{aligned}$
$\begin{aligned} & \text { Duarte et al. } \\ & (1997)\end{aligned}$ up to 66.6\%

Effect of indolebutyric acid on rooting of softwood cuttings
of 'Sabará' Jabuticaba tree $(M$. jaboticaba) under nebulization

of 'Sabará' Jabuticaba tree (M. jaboticaba) under nebulization $\begin{gathered}\text { Scarpare Filho et } \\ \text { al. (1999) }\end{gathered} \quad$ up to $38 \%$ conditions

Effect of tree blanching and IBA on rooting of softwood cuttings of Casagrande Jr. et
Jabuticaba tree ${ }^{3}$
al. (2000)

up to $2.6 \%$

Effects of substrates, $\mathrm{pH}$ values, IBA concentrations on rooting of

Jabuticabeira terminal cuttings [Myrciaria jaboticaba (Vell.) O.

Berg.]

Pereira et al.

(2005) up to $32.3 \%$

\begin{tabular}{lcc}
\hline Jabuticabeira Rooting (P. trunciflora) by aerial plunged ${ }^{4}$ & $\begin{array}{c}\text { Danner et al. } \\
(2006)\end{array}$ & up to $100 \%$ \\
\hline Propagation of Jabuticaba tree by cutting ${ }^{3}$ & $\begin{array}{c}\text { Sasso et al. } \\
(2010 \mathrm{a})\end{array}$ & $\begin{array}{c}\text { up to } 50 \% \text { woody and } 10 \% \\
\text { softwood }\end{array}$ \\
\hline Propagation of Jabuticaba tree by grafting and air layering & $\begin{array}{c}\text { Sasso et al. } \\
(2010 \mathrm{~b})\end{array}$ & $\begin{array}{c}\text { up to } 72.9 \% \text { grafting and } \\
87.5 \% \text { air layering }\end{array}$ \\
\hline
\end{tabular}

${ }^{1}$ : Rooting for cutting and air layering researches and sprouting for grafting researches. ${ }^{2}$ : Jabuticaba tree from Plinia cauliflora species. ${ }^{3}$ : Erroneously, the species was classified in the article as P. trunciflora, but belongs to P. cauliflora. ${ }^{4}$. There was only callus formation.

\section{Final considerations}

From the information available in form of scientific paper on 'Jabuticaba' tree propagation techniques, it appears that one of the first publications, it was demonstrated the feasibility of grafting (SAMPAIO, 1984). After this, most publications focused on trying to solve the problem of low rooting of cuttings, mainly from softwood cuttings during nearly two decades of research in different parts of Brazil. The feasibility of air layering was demonstrated in two studies (Table 1).

Due to the rooting difficulty of 'Jabuticaba' cuttings, for the cutting technique, a protocol to be followed for efficient production of seedlings in nurseries is not yet defined, and it is necessary to improve the technique through new experiments.

So, the options for production of clonal seedlings of the species is the use of grafting (top-cleft graft) to produce a large number of plantlets in nurseries, or, also, the realization of air layering, in the place of origin of the selected mother plants, which provides higher seedling formation rate. Observations indicate that the grafted or air layering enter into production after four years of planting, anticipating when compared to the seedlings via seeds. For both techniques (grafting and air layering), the protocols described above can be followed, based on the results of the reviewed articles cited in this article.

\section{References}

BALERDI, C.F.; RAFIE, R.; CRANE, J. Jaboticaba (Myrciaria cauliflora, Berg.): a delicious fruit with an excellent market potential. Proceedings of the Florida State Horticultural Society, Bradenton, v.119, p.66-68, 2006.

BRESSAN, E.A.; SEBBENN, A.M.; FERREIRA, R.R.; LEE, T.S.G.; FIGUEIRA, A. Jatropha curcas L. (Euphorbiaceae) exhibits a mixed mating system, high correlated mating and apomixis. Tree Genetics \& Genomes, Heidelberg, v.9, p.1089-1097, 2013. 
CASAGRANDE JÚNIOR, J.G.; DUTRA, L.F.; TONIETTO, A.; NACHTIGAL, J.C.; STRELOW, E. Efeito do estiolamento de ramos e do AIB no enraizamento de estacas herbáceas de jabuticabeira. Revista Brasileira de Agrociência, Pelotas, v.6, n.1, p.24-26, 2000.

CORDEIRO, M.C.R.; PINTO, A.C.Q.; RAMOS, V.H.V.; FALEIRO, F.G.; FRAGA, L.M.S. Identificação da origem genética de plântulas em sementes poliembriônicas de mangueira (Mangifera indica, L.) cv. Rosinha por meio de marcadores RAPD. Revista Brasileira de Fruticultura, Jaboticabal, v.28, n.3, p.454-457, 2006.

CRUZ, E.S.; DANTAS, A.C.V.L.; CARMO, C.D.; BASTOS, L.P. Molecular characterization of jaboticaba tree genotypes located in the municipalities of recôncavo of Bahia. Revista Brasileira de Fruticultura, Jaboticabal, v.38, n.3, 2016. Falta páginas.

DANNER, M.A.; CITADIN, I.; JUNIOR, A.A.F.; ASSMAN, A.P.; MAZARO, S.M.; DONAZZOLO, J.; SASSO, S.A.Z. Enraizamento de jabuticabeira (Plinia trunciflora) por mergulhia aérea. Revista Brasileira de Fruticultura, Jaboticabal, v.28, n.3, p.530-532, 2006.

DANNER, M.A.; CITADIN, I.; SASSO, S.A.Z.; AMBROSIO, R.; WAGNER JÚNIOR, A. Armazenamento a vácuo prolonga a viabilidade de sementes de jabuticabeira. Revista Brasileira de Fruticultura, Jaboticabal, v.33, n.1, p.246-252, 2011 b.

DANNER, M.A.; CITADIN, I.; SASSO, S.A.Z.; SCARIOT, S.; BENIN, G. Genetic dissimilarity among jabuticaba trees native to Southwestern Paraná, Brazil. Revista Brasileira de Fruticultura, Jaboticabal, v.33, n.2, p.517-525, 2011a.

DANNER, M.A.; CITADIN, I.; SASSO, S.A.Z.; TOMAZONI, J.C. Diagnóstico ecogeográfico da ocorrência de jabuticabeiras nativas no Sudoeste do Paraná. Revista Brasileira de Fruticultura, Jaboticabal, v.32, n.3, p.746-753, 2010

DONADIO, L.C. Jabuticaba. In: SAMPAIO, C.V.; SANTOS-SEREJO, J.A.; DANTAS, J.L.L.; COELHO, Y.S. Fruticultura tropical espécies regionais e exóticas. Brasília, DF: Embrapa, 2009. p.239-257.

DUARTE, O.R.; HUETE, M.; LÜDDER, S.P. Propagation of jabuticaba (Myrciaria cauliflora (Mart.) Berg.) by terminal leafy cuttings. Acta Horticulturae, The Hague, n.452, p.123-128, 1997.
LEITE-LEGATTI, A.V.; BATISTA, A.G.; DRAGANO, N.R.V.; MARQUES, A.C.; MALTA, L.G.; RICCIO, M.F.; EBERLIN, M.N.; MACHADO, A.R.T.; CARVALHOSILVA, L.B.; RUIZ, A.L.T.G.; CARVALHO, J.E.; PASTORE, G.M.; MARÓSTICA JÚNIOR, M.R. Jaboticaba peel: Antioxidant compounds, antiproliferative and antimutagenic activities. Food Research International, London, v.49, p.596-603, 2012.

LENQUISTE, S.A.; BATISTA, A.G.; MARINELI, R.S.; DRAGANO, N.R.V.; MARÓSTICA JÚNIOR, M.R. Freeze-dried jaboticaba peel added to high-fat diet increases HDL-cholesterol and improves insulin resistance in obese rats. Food Research International, London, v.49, p.153-160, 2012.

LEONEL, S.; VARASQUIM, L.T.; RODRIGUES, J.D.; CEREDA, E. Efeito da aplicação de fitorreguladores e ácido bórico em estacas de jabuticabeira (Myrciaria cauliflora Berg.). Revista Brasileira de Fruticultura, Jaboticabal, v.13, n.3, p.219- 222, 1991.

PEREIRA, M.; OLIVEIRA, A.L.; GONÇALVES, A.N.; ALMEIDA, M. Efeitos de substratos, valores de $\mathrm{pH}$ e concentrações de AIB no enraizamento de estacas apicais de jabuticabeira [Myrciaria jaboticaba (Vell) O. Berg.]. Scientia Florestalis, Piracicaba, n.69, p.84-92, 2005.

RUIZ, C.; BRETO, M.P.;ASÍNS, M.J.Aquick methodology to identify sexual seedlings in citrus breeding programs using SSR markers. Euphytica, Dordrecht, v.112, p.8994, 2000.

SAMPAIO, V.R. Propagação por enxertia do Sabarazeiro. Anais da ESALQ, Piracicaba, v.41, n.1, p.135-140, 1984.

SASSO, S.A.Z.; CITADIN, I.; DANNER, M.A. Propagação de jabuticabeira por estaquia. Revista Brasileira de Fruticultura, Jaboticabal, v.32, n.2, p.577583, 2010a.

SASSO, S.A.Z.; CITADIN, I.; DANNER, M.A. Propagação de jabuticabeira por enxertia e alporquia. Revista Brasileira de Fruticultura, Jaboticabal, v.32, n.2, p.571-576, 2010b.

SCARPARE FILHO, J.A.; NETO, J.T.; COSTA, J.W.H.; KLUGE, R.A. Efeito do ácido indolbutírico no enraizamento de estacas herbáceas de jabuticabeira Sabará (Myrciaria jabuticaba), em condições de nebulização. Revista Brasileira de Fruticultura, Jaboticabal, v.21, n.2, p.146-149, 1999. 
VIEIRA, V.L.L.P.; FERREIRA, W.R. A festa da jabuticaba e o empreendedorismo feminino no município de Sabará/ MG. Revista Brasileira de Gestão e Engenharia, São Gotardo, n.8, p.1-28, 2013.
WAGNER JÚNIOR, A.; COSTA E SILVA, J.O.; PIMENTEL, L.D.; SANTOS, C.E.M.; BRUCKNER, C.H. Germinação e desenvolvimento inicial de duas espécies de jabuticabeira em função do tamanho de sementes. Acta Scientiarum - Agronomy, Maringá, v.33, n.1, p.105-109, 2011. 